\title{
Understanding the Syria Babel: moral perspectives on the Syrian conflict from just war to Jihad
}

Article

Accepted Version

Smith, T., Lee, P., Rauta, V. and Khalfey, S. (2020)

Understanding the Syria Babel: moral perspectives on the Syrian conflict from just war to Jihad. Studies in Conflict and Terrorism, 43 (12). pp. 1108-1128. ISSN 1521-0731 doi: https://doi.org/10.1080/1057610X.2018.1523358 Available at https://centaur.reading.ac.uk/79836/

It is advisable to refer to the publisher's version if you intend to cite from the work. See Guidance on citing.

To link to this article DOI: http://dx.doi.org/10.1080/1057610X.2018.1523358

Publisher: Taylor and Francis

All outputs in CentAUR are protected by Intellectual Property Rights law, including copyright law. Copyright and IPR is retained by the creators or other copyright holders. Terms and conditions for use of this material are defined in the End User Agreement.

www.reading.ac.uk/centaur 
Central Archive at the University of Reading

Reading's research outputs online 
Accepted Post Print

Journal Article - Studies in Conflict and Terrorism, Print ISSN: 1057-610X Online ISSN: 1521-0731

Accepted: 31 August 2018 


\section{Understanding the Syria Babel: Moral Perspectives on the Syrian Conflict from Just}

\section{War to Jihad. ${ }^{1}$}

\section{Authors:}

- Tom Smith, (corresponding author) University of Portsmouth, tom.smith@port.ac.uk,

- Peter Lee, University of Portsmouth, UK

- Sameera Khalfey, University of Portsmouth, UK

- Vladimir Rauta, University of Reading, UK

\section{Abstract:}

The war in Syria, and its ongoing analysis, is burdened by a variety of seemingly irreconcilable political motivations, actions, ideologies, religious affiliations and power dynamics of multiple state and non-state actors. In this context, various moral perspectives appear to come into direct conflict, underpinning the actions of the actors involved and to varying degrees influencing their competing political interests. Is there a coherent dialogue of moralities between the rivals involved or is Babel reborn with moral claims being launched but with no real exchange of meaning involved? On Syria, the answer is a complicated mixture of both but within which are important and as yet underappreciated patterns of convergence and divergence. This paper looks at the leading states involved as well as the role of individuals to elucidate this pattern of overlap and difference in the morality discourses surrounding Syria. Ultimately, it is argued that a moral Babel is not reborn in Syria: there is sufficiently common moral language being used by all sides for a degree of shared meaning to emerge. The challenge is for the protagonists to listen and really hear what is being said and work with those commonalties as tools towards peace.

\section{Keywords:}

Syria, jihad, morality, just war, Russia, human rights, ISIS, conflict, terrorism 
'The sad reality is that Syria is a morally ambiguous conflict, for which there may be no Western solution at all ${ }^{2}$

Following an uprising by opposition forces against the government of President Bashar al Assad in 2011, Syria has descended into a morass of civil war, proxy war, jihad, insurgency, and ideological struggle, with clashing geopolitical, regional and local interests resulting in a series of humanitarian and political crises. By 2014, with years of intense fighting to follow, the UN reported 2.6 million refugees, 6.5 million internally displaced people, war crimes, crimes against humanity, sexual abuse, torture and other abuses in Syria, with the Syrian government, Jabhat Al-Nusra and ISIS (Islamic State of Iraq and Syria) identified as perpetrators. ${ }^{3}$ The war in Syria, and its ongoing analysis, is burdened by a variety of seemingly irreconcilable political motivations, actions, ideologies, religious affiliations, and power dynamics of multiple state and non-state actors. In this context, various moral perspectives appear to come into direct conflict, underpinning the actions of the actors involved and to varying degrees influencing their competing political interests. Thus far there have been limited attempts to understand the moral basis for the use of military force by the key protagonists in Syria and the related importance of those moral claims where they are made. This presents a puzzling set of questions: given the overlap of both complementary and contrasting moral authorities, how coherent is the dialogue between these moralities and, more importantly, to what extent does it shape the direction of the conflict? To answer these questions, the article develops a heuristic under the metaphor of 'the Syrian Babel' to explain that competing moral claims shape the conflict through the inability to produce any significant constructive exchange or dialogue. The heuristic harnesses the underappreciated patterns of convergence and divergence across these moral positions to offer an analytical vantage point.

The complexity of the Syrian civil war is underlined at first glance by the multiplicity of actors involved that diffusion the violence into a layered macro, mezzo, and micro set of 
dynamics. The literature has so far explored how these have interacted across established patterns of strategic behaviour ranging from classic inter-state alliances (Russia-Syria), punitive shortterm military interventions (USA-France-UK) and indirect proxy engagements (USA and some Kurdish forces, to name one of a myriad of examples). Yet, one facet of these interactions remains unexplored and it concerns the moral underpinning of the politico-strategic behaviour of the actors segmenting the conflict space in Syria. The article argues that the ever-growing number of actors involved in Syria gives space to a heterogeneous moral mix with significant consequences for the direction and future of the civil war. We label this issue the 'Syrian Babel' and use this heuristic to observe how plural moral discourses push the direction of the conflict away from peaceful resolution on grounds of axiological divergence and in spite of any claim of moral convergence.

This has been evident from the early days of the demonstrations and has amplified throughout the course of the conflict. On the one hand, President Assad's government has used chemical weapons against opposition groups, ${ }^{4}$ and the Violations Documentation Center in Syria has monitored further human rights violations by both government and opposition forces since $2011 .^{5}$ On the other hand, ISIS jihadists have carried out systematic enslavement and rapes of Yazidi girls and women as honourable acts of divine fealty within its interpretation of the Qur'an. ${ }^{6}$ Adding to this, a 2012 UN Human Rights Council report concluded that the situation had 'met the legal threshold for a non-international armed conflict'. At that juncture the Independent International Commission of Inquiry on Syria established by the UN Human Rights Council decided to apply both international humanitarian law (IHL) and international human rights law (IHRL) to the situation. In so doing, it introduced parallel state-rights and individualrights dimensions to its analysis. To these, the Russian normative position adds weighted complication for since 2012 President Putin has 'positioned Russia as the saviour of the moral foundations of the Western civilization', ${ }^{8}$ intensifying his public and military support to the Assad regime over the same period. 
As the conflict unfolded with massive casualties and historically high displacement, the Western discourse added another moral discursive layer, in spite of its vacillatory character. In 2015 Prime Minister David Cameron explicitly justified the United Kingdom's first overt military action in Syria - the killing of two British citizens in a Reaper (drone) strike - in language long associated with the Western just war tradition referring to 'the UK's inherent right to self-defence' and 'the principles of proportionality and military necessity'. ${ }^{9}$ Then in April 2017 President Trump ordered a major US air strike against a Syrian air base in response to the use of chemical weapons by Assad's Syrian regime. ${ }^{10}$ All these moral positions translated into evident mutual antagonisms, which is what the Syrian Babel heuristic locates. More importantly, they reproduced themselves into a complicated dialogue of moral claim and counter-claim. This then raises the article's central question: how do we make sense of this heterogeneity and plurality of moral alternatives?

The presence of moralism within the political discourse shifts the focus of political action to that which is legitimised and limited by moral principles. The work of Walzer serves us here to highlight how aspects of moral plurality and heterogeneity can occur across different contexts in 'a mutually comprehensible fashion,' using vocabulary that overlaps even when arguments do not. ${ }^{11}$ Thus, whilst this paper may identify distinct moral systems for the US, Russia, Saudi Arabia, Iran and Jihadists, the underlying concept of principles based on achieving 'good' directs and legitimises actions and reactions, remaining consistent across differing principles. Further, Walzer developed the idea of a shared 'moral world of war' that emerges because 'we acknowledge the same difficulties on the way to our conclusions, [we] face the same problems, talk the same language.' 12 The article's argument questions the extent to which Walzer's assumptions about 'talk[ing] the same moral language' hold true when Western just war ethics and the morality of the jihad are considered in the Syrian context. ${ }^{13}$ This is crucial because without some understanding and mapping of the moral dimension of both allies' and foes' motivations and actions, we are more likely to remain trapped in a seemingly intractable web of 
opposing political and strategic interests. As this article will highlight, the strategic and political interests, especially of the regional powers, are often primary - though hybridised in the space of a figurative yet veritable Tower of Babel by a complex of overlapping and competing moral claims.

Following a brief synopsis of the Syrian conflict, the two main sections of the paper will explore, first, the moral basis of Western military intervention as it is articulated in American and British political discourse and contrasted with that of Russia. The second section dissects the Sunni Islamic moral approach to war and its place in Saudi Arabia's political discourse in relation to Syria and is compared against its regional counterpart Iran. It will then be contrasted with the complex role of morality in the jihad ${ }^{14}$ which extends from direct participants in violence to those who engage with moral discourses on Syria freely through social media platforms.

\section{The Syrian Conflict and Moral Discursive Heterogeneity}

Amnesty International has testified to 'serious violations of international humanitarian law and grave abuses of human rights,' ${ }^{15}$ with civilians being the focus of much of the violence. By 2017, millions of Syrians had been displaced and the UN reported 643,780 people living under siege, 'militarily encircled' with no access to humanitarian support; attacks on civilians and civilian infrastructure in Alleppo, Homs and other key centres of population resulting in acute water shortages; attacks on UN and humanitarian organisations; and multiple human rights abuses. ${ }^{16}$ Acts of violence in Syria between government and competing opposition groups would include abduction, rape, sexual violence, torture, physical abuse and the use of chemical weapons. ${ }^{17}$ By March 2017, 5 million Syrians were externally displaced as refugees, ${ }^{18}$ with a further 6.3 million internally displaced ${ }^{19}$ and caught between opposing interests and actors. The scale of the violence, and its consequences, is matched in the complexity of its justification at the level of moral discourse, both inside and outside Syria. ${ }^{20}$ 
Common moral ground - or even Walzer's sense of common moral language - amongst any of the 'sides' in this war (even assessed in the most simplified fashion) is, at least on the surface, hard to find. Different Syrian opposition forces, supported separately by Qatar and Saudi Arabia, ${ }^{21}$ comprise a constantly mutating alliance of rebel groups, from the Free Syrian Army (created by defected Syrian military officers) to Salafi Jihadist groups such as Fatah al-Islam, who share a common enemy in the Assad regime. The Syrian Opposition is loosely united in fighting a common foe, rather than by shared ideology - either secular or religious. That enemy, the Syrian Government of the Assad regime, is also allied with local and regional groups ranging from the more secular Ba'th Brigades and the Marxist-Leninist Syria Resistance group ${ }^{22}$ to Shia militias and forces of Hezbollah and the Quds Force of the Iranian military.

Outside Syria, the breadth and depth of international involvement complicates the ability to apply a consistent moral language. Alliances between Syria, Lebanon, Iran and Russia are "longstanding, dating back to the Khrushchev era"23 are been fully exercised, if not expanded in the conflict. ${ }^{24}$ Meanwhile, two opposition coalitions are supported in the conflicts against ISIS (and for the most part not directly against the Assad regime) through the Combined Joint Task Force - Operation Inherent Resolve (CJTF-OIR) led by the United States and reinforced by other nations including the UK and France. While CJTF-OIR and the other international parties involved are bonded by the threat of ISIS, morality discourse in Syria is complicated further by the involvement of a spectrum of jihadist groups from ISIS to Jabhat Fateh al-Sham (formerly Al-Nusra Front). Against such an evolving and complex backdrop, the complexity of the moral universes of Syrian civil war dynamics can be labelled 'the Syrian Babel' as a heuristic to capture its heterogeneity. Within this Syrian Babel the moral discourses of Western intervention stand in direct competition with those of its Eastern counterpart. The next section explores their divergence by looking first through a US/UK lens and then contrasting the approach with morality claims in Russia's intervention discourse.

\section{Syria, just war and the morality of Western intervention}


Western interventionist political discourse concerning Syria is characterized by a tension between state-centric and individual-focused moral arguments. At a theoretical level a parallel tension has become increasingly apparent between advocates of idealized, individual rightsbased just war like McMahan ${ }^{25}$, and advocates of more pragmatic, collective rights-based just war like Walzer and his 'legalist paradigm'. ${ }^{26}$ The following discussion will identify the differences that emerge in these approaches and also consider whether they conform to Walzer's assumption of common moral language through which meaning is contested, or whether more fundamental incommensurabilities are in operation.

\section{Morality and military intervention: perspectives from the UK and US}

The American approach to Syria under President Obama, both politically and militarily, was consistently presented in moral terms using the language of values and just war located at the intersection of state rights and responsibilities with human rights. Prior to the escalation of violence in Syria, in his Nobel Lecture, Obama spoke of thinking 'in new ways about the notions of just war and the imperatives of a just peace' in the context of civil wars, failed states, ruined economies, refugee crises and 'morally justified' use of force. ${ }^{27}$ Later that year, in response to the use of chemical weapons by the Assad regime, Obama stated that 'our security and our values demand that we cannot turn away from the massacre of countless civilians with chemical weapons' ${ }^{28}$ Continuing the theme, in 2015 at the UN, Obama advocated the use of military force to support the pursuit of 'a just and lasting peace' in Syria. ${ }^{29}$ Over that period, Obama backed military intervention - by the US and its allies - as well as coordinated international action, to oppose individual human suffering, the killing of innocents and the enslavement of women, in support of 'democratic principles and human rights'.

Similarly, in the UK on 23 August 2013, British Prime Minister David Cameron set out his case for military intervention in Syria, based primarily on the Assad regime's 'morally indefensible and completely wrong' use of chemical weapons against civilians, causing 
'appalling scenes of death and suffering'. ${ }^{31}$ The tension between the rights of states - represented by the Assad regime - and the rights of individuals not to suffer at the whim of the state, sat at the centre of moral justification for military intervention. Several days later Cameron's government set out its legal case for intervening militarily across Syrian state borders, based on the moral imperative to 'relieve human suffering'. ${ }^{32}$ It argued that 'a legal basis is available, under the doctrine of humanitarian intervention' for a 'use of force [that is] necessary and proportionate to the aim of relief of humanitarian need' and to 'protect civilians' ${ }^{33}$ In just war terms, Cameron's and the UK government's cases were presented as a last resort in pursuit of the just cause of protecting civilians, using proportionate but necessary means. The British state should act to protect Syrian citizens from their government, as well as from opposition groups specifically ISIS. However, parliamentarians referred to, then rejected, the UN 'Responsibility to Protect' (R2P) doctrine which supports humanitarian intervention in the face of genocide, war crimes, ethnic cleansing and crimes against humanity ${ }^{34}$ Despite the evidence of violence against civilians, being conducted by the Assad regime and opposition groups cited by Cameron, on 29 August 2013 the British parliament voted against military intervention in Syria. The vote was multi-layered for many parliamentarians but ultimately because "the Security Council reserved the exclusive right to decide when the doctrine known as R2P (Responsibility to Protect) applied", 35 Cameron's case for liberal intervention failed.

However, with the 2015 drone killing of two British citizens in Syria, Reyaad Khan and Ruhul Amin, 'under the doctrine of national defence' Cameron departed from the 2013 individual rights-based argument towards a state-based argument. ${ }^{36} \mathrm{He}$ described the strikes as 'exercising the UK's inherent right to self-defence', complying with international law and - in the vocabulary of orthodox just war's jus in bello principles as well as international humanitarian law- 'the principles of proportionality and military necessity'. ${ }^{37}$ Cameron's position was reinforced by the UK Attorney General, Jeremy Wright, in evidence to the UK Parliament Justice Select 
Committee on 15 September 2015 that was also framed in the language and concepts of state rights and responsibilities. He stated:

...in order for any state to act in lawful self-defence, it is necessary to demonstrate that there is an imminent threat that needs to be countered and that, in countering that threat, the action taken is both necessary and proportionate, and it is necessary to demonstrate that what you do complies with international and humanitarian law. In all of those respects I was satisfied that this was a lawful action. ${ }^{38}$

While Cameron and Wright were primarily concerned with setting out - within limits the UK's legal position regarding the killings, there are implications for just war moral analysis of the action. Cameron's unsuccessful 2013 attempt to gain UK parliamentary approval for military intervention in Syria was based on a desire to protect civilians - particularly their individual right to life. For the 2015 intervention by drone strike he and the Attorney General framed their decision-making decidedly in terms of the state: the UK's right to self-defence and associated international humanitarian law. In just war terms, individual-rights based moral arguments associated with McMahan ${ }^{39}$ appear to have been set aside in favour of reasoning and actions that can more consistently be interpreted through Walzer's state-based, just war 'legalist paradigm.${ }^{40}$ However, at this point it would be too simplistic to place Walzer and McMahan and their respective state-based and individual-based just war positions - too strongly in opposition. Walzer acknowledged that '[i]ndividual rights (to life and liberty) underlie the most important judgements that we make about war,' recognizing that '[s]tates' rights are simply their collective form' ${ }^{41}$ Both the degree of threat posed by Khan and Amin to the UK and its citizens, as well as Cameron's decision to kill Khan and Amin in Syria, can be disputed in a meaningful manner because the actions and language involved could be readily understood by supporters and opponents alike from both state and individual perspectives. 
Opposition to the killings, however, was not dominated by arguments over the violation of Syrian sovereign territory, nor was it rooted in evidence of disproportionate force, in opposition to Cameron's claim. Rather, a more circuitous opposing argument about the legitimacy of the action was based on whether or not the UK was either directly or indirectly in armed conflict with Syria and therefore whether IHL or IHRL applied. ${ }^{42}$ That distinction is crucial in legal terms, in turn part of broader just war moral dialogue. At a philosophical level, the conventional, collectivist just war paradigm articulated by Walzer - and operationalised in this instance by Cameron - has been countered by shifting the parameters of the debate. The discursive manoeuvre takes the following form: reject IHL as a legitimate basis for the UK's drone killing of Khan and Amin; shift the basis of the legitimacy calculus to human rights and IHRL; bring 'extraterritorial UAV attacks ... within the [human rights] jurisdiction of the operating State'; confirm the illegitimacy of the drone strike with reference to the violation of human rights in the case. ${ }^{43}$

The problem with this approach in trying to discern or respond to the just war elements of the argument made by Cameron is that the proponents of competing IHL/IHRL approaches use similar vocabularies to articulate opposing ideas. For Clark, this polarizing of just war perspectives 'now presents a serious obstacle to genuine dialogue'. ${ }^{44}$ Morality discourses within early British and American political attempts to justify military intervention in Syria initially placed a strong emphasis on protecting (Syrian) individuals and their right to life. When military action finally took place the primary justifications, or at least the British public justifications, were framed more by placing the rights and responsibilities of states to defend themselves and their citizens ahead of the individual rights of those who would threaten them. If the story of Babel is of the confusion sown by a lack of common language, the story of applying Western just war to Syria is of confusion and opposition rooted in a shared - not misunderstood - moral language. In this context, Russia’s moral perspective provides a challenging counterpoint.

\section{Russia, 'morality' politics and military intervention}


In his 2015 address to the $70^{\text {th }}$ session of the United Nations General Assembly, President Putin highlighted the importance of state sovereignty and made a case for plural political approaches in the international arena, stressing: 'We are all different. And we should respect that'. ${ }^{45}$ Putin sought to differentiate Russia from other Western powers ${ }^{46}$ by blaming the latter most notably the US - of trying to standardise foreign policy praxis around strength and selfinterest, irrespective of scenario. In articulating support for Assad's government and its 'valiant' fight against ISIS and other terrorists groups, Putin put forward the case for accepting diversity of foreign policies, of political options and of alliance models. ${ }^{47} \mathrm{He}$ stated, 'Everything that contravenes the UN Charter must be rejected', positioning himself, politically and morally, in the state-based framework of the UN Charter in international law. ${ }^{48}$ At the core was the case for a Russian foreign policy approach that refuted Western values, as expressed in globalization, and American unilateralism. ${ }^{49}$

Russia claims a moral basis for its involvement in Syria, a basis that is framed and acknowledged as different from its US or UK equivalent, and with a unique origin. If, 'in the aftermath of the demise of the Soviet empire, the new [Russian] leadership and the elites embarked on a quest for a new sense of national identity', it was only recently that the notion of state identity came to be employed in a consistent fashion. ${ }^{50}$ With it, 'the state has gone from forgotten to focal point' ${ }^{51}$ In parallel, morality discourses have also evolved from the fringe to the centre of constructing both policy and politics in present day Russia. The political agenda has often led to state-influenced media outlets promoting 'conservative themes [such] as homophobia, the Russian Orthodox Church, and chauvinistic gender roles'. ${ }^{52}$ This allows for a characterisation of Russian 'morality' as fundamentally heteronormative and anti-feminist, and helps locate the basis of morality within a particular interaction as here with Syria and its military intervention in support of the Syrian regime. ${ }^{53}$

Expressed in Russia's domestic policies, and enacted in its foreign policies - including reference to Syria - this 'morality politics' is dated by the Pussy Riot trial in 2012 that the 
Kremlin used to advance its new discursive frame in public. Although not entirely new in its orientation, this stage of morality politics differed from the earlier policy initiatives in its intensity, scope and political significance for the regime. ${ }^{54}$ In the Russian conception, as a politicising value, it is authoritative, intransigent and inflexible because it admits virtually no degree of perfectibility outside its boundaries. It is for this reason that President Putin ' $[\ldots]$ took upon himself the mantle of the champion of conservative values worldwide and positioned Russia as the saviour of the moral foundations of the Western civilization'.55

This combination of an internally based moral imperative to support state interests and a state-centric foreign policy, all reinforced Putin's commitment to preserving the Syrian state. In 2015 he said, 'There is no other solution to the Syrian crisis than strengthening the effective government structures and rendering them help in fighting terrorism, ${ }^{56}$ This is a moral as well as political position, with legitimacy conferred by effective governance and conformity to international law. Putin subsequently stressed Russia’s 'full compliance with international law' with regard to its involvement in Syria, pointing out that other countries were 'acting unlawfully' because of the lack of UN Security Council resolution and the absence of an official request from the Syrian authorities. ${ }^{57}$

For Russia, sovereignty is 'spiritual freedom' that is defended through a strong and socially protective state. ${ }^{58}$ It is for this reason that Putin has called for the pursuit of a political settlement to the Syrian civil war that would involve the Syrian government as the elected representatives of the state. A functioning state is attributed with inherent moral worth in Russia's justification of intervention. The moral duty of Russian citizens to preserve Russia in the face of terrorism provides a further basis for the intervention in Syria. The purpose of Russian intervention is 'to combat terrorism and to help President al-Assad gain victory over terrorism, which in turn would create conditions for the beginning and, hopefully, successful implementation of a political settlement'. ${ }^{59}$ While the Russian stance on Syria 'is informed by a number of consideration[s] and interests, at both an international and a regional level', ${ }^{60}$ the official rationale for the 
intervention stems from the Russian state's moral obligation towards its citizens and towards itself as a country in the face of terrorism.

When confronted by criticism that Russian air strikes had killed civilians in Syria in 2016, Putin rejected the claims and emphasized that Russia's priority was to prevent the Syrian state from collapsing, as Libya did once Colonel Gaddafi was ousted in $2011 .^{61}$ Further, the Russian Foreign Ministry sidestepped the issue of non-combatant deaths, stating that it had 'not received convincing evidence of civilian deaths as a result of Russian air strikes'. ${ }^{62}$ Any Russian concern for the rights or lives of individuals in Syria has been consistently undermined by its use of force in support of the Assad government and the explicit prioritizing of regime and state survival. Given Cameron's appeal to the UK's right to self-defence in his use of military force in Syria, it would be overly simplistic to assume that Putin's approach manifests only realist self-interest. This brief Russian juxtaposition demonstrates a clear moral component to Russian actions and motivations: incorporating a political dimension that prioritizes the state over the individual, and a social component that advocates conservative values. In these terms, Russia exemplifies at least a degree of Walzer's communitarianism and, similarly, suffuses state rights-based claims with acknowledgement of some degree of individual rights. This logic is not singular to Russia however. In the next section, the paper moves on to discuss the moral basis of Saudi Arabia's actions in relation to Syria, and a similar prioritizing of state interests will be identified. Consistent with the Syrian Babel heuristic, while an overt religious dimension will be explored, its significance will be subsequently questioned when compared to concern for the individual as the paper comparatively examines the moral basis of jihadist actions in Syria.

\section{Syria, Saudi Arabia and traditional Islamic morality}

Islamic political morality is rooted in the teachings of the Qur'an (Islamic holy book) and the Sunnah (recorded teachings of the Prophet Mohammed). Unlike other Abrahamic faiths, Islam's prescription for its followers is said to be holistic: spiritual and political. The Qur'an and 
Sunnah, through varied interpretations (ijtihad), establish acceptable interactions and actions between groups of people, including rules of engagement in warfare. For example, the identification of non-combatants and their treatment, and the identification of valid and invalid targets. ${ }^{63}$ 'Islamic' political morality thus differs, according to the school of thought followed Sunni, Shia and within these Shafi'i and Alawite respectively - which further informs varied interpretations of the conduct of war. Hashmi suggests that two principles pervade Islamic political morality: 'Idealistic Realism' and 'Moral Innocence'. ${ }^{64}$ For Hashmi, this 'Idealistic Realism' embodies Islam's recognition of the reality of war and its simultaneous pursuit for peace, which 'undermines the possibility of an Islamic pacifism' ${ }^{65}$ However, the term is highly unsatisfactory - incomprehensible even - when read through the lens of Western political theory. The contradictions of realism and idealism, generally understood, are thrust together with no obvious resolution in Hashmi's analysis. However, there are echoes of principles that are identifiable in Western just war theory within Islamic concepts of just cause, just conduct and just peace, as Kelsay has argued. ${ }^{66}$ So these religious influences on morality with regards to Syria are complicated further with significant overlap from both individual and state perspectives, and between Muslim and non-Muslim.

Attempting to identify commonality of meaning across Western and Islamic just war beyond a superficial identification of the vocabulary involved - and attempting to recognise even small areas of common ground is challenging. While the 'Qur'ān teaches that war must be limited and conducted in 'as humane a way as possible', ${ }^{67}$ language intrudes again: what is 'humane' is dictated by interpretation in sometimes competing schools of Islamic thought. The most basic division of Islam into Sunni and Shi'i sects provides plenty of scope for interpretational differences between and within the separate traditions. While the Shi'i influence on the conflict in Syria is significant, the focus here remains on the Sunni stream of thought. It is influenced by Ijtihad, fiqh, and as Sachedina states, 'the socio-political circumstances of the Muslim 
community'. ${ }^{68}$ Further, differing schools of Islamic thought form al-Siyar, which is the Sunni equivalent of international law. ${ }^{69}$

For Kelsay, Islamic ways of thinking and talking about war 'resonate with the [Western] just war tradition' ${ }^{70}$ On the surface, his arguments seem convincing, at least when expressed in the

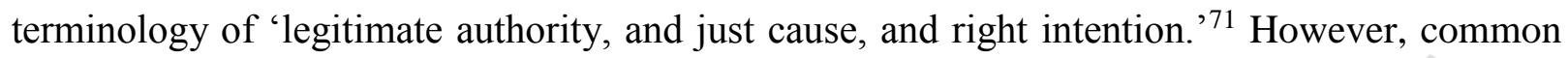
terminology tempts the reader to ignore the signs of Babel re-emerging in the miscommunication of ideas. Setting aside the complexity of competing Islamic schools of thought, legitimate authority in Islamic just war, as described by Kelsay, is necessarily rooted in God's revelation as captured in the Qur'an and demonstrated in the practice of the Prophet. There is no scope for the Western just war advocate to recognise 'legitimate authority' on that basis: neither the orthodox, state-based legalist just war approach of Walzer, nor the individual-based just war of McMahan. Both of these latter Western just war approaches are rejections of the Christianized, religiousbased just war of earlier centuries. The most credible conceptual overlap between Islamic 'legitimate authority' and Western 'legitimate authority' occurs when the former is juxtaposed with, say, the thirteenth century just war writings of Aquinas. ${ }^{72}$ However, the meaning of legitimate authority would still be disputed in the theological disputes that would follow. These complexities find a direct expression in the Syrian civil war, and a brief overview of Saudi Arabian and Iranian approaches to Syria shows the counter-convergent role of these moral layers that not only propose alternative views but translate directly into the relationship between politics and morality.

\section{Saudi Arabia and Iran: Foreign policy and morality}

As guardians of the Sunni and Shia faiths, Saudi Arabia and Iran (respectively) represent states influenced by religious belief systems. They also represent two opposing external factions within the Syrian conflict with noteworthy moral claims. Both Saudi Arabia's and Iran's actions in Syria are motivated by their attempts to benefit from Syria's geostrategic value within the 
region and their inherently political actions are reinforced through religious and moral claims. These moral claims differ, yet simultaneously share significant similarities in places with not just one another but also with the perspectives of Russia, the UK and the US.

Saudi Arabia's foreign policy is dictated by four circles of influence: the Gulf circle, the Arab circle, Islamic circle, and the international circle, each suffused with the moral language of protection and responsibility. ${ }^{73}$ Its strategy highlights its focus on regional politics while Iran, in contrast, has historically been isolationist in its foreign policies, though covert actions through Hezbollah represent its desire to impact regional politics. ${ }^{74}$ Iranian actions are rooted in the aims and objectives of its Islamic revolution, an ideological basis that contrasts with Saudi Arabia's conservatism, and its strategic alliance with the US. ${ }^{75}$ 'The foreign policy of the Kingdom of Saudi Arabia is based on geographical - historical - religious - economic - security - political everlasting principles and facts'. ${ }^{76}$ This is manifest in the actions undertaken in Syria, where Saudi Arabia has aligned itself with rebel groups, reinforcing Sunni forces, whilst also pursing both the peace process and attacks on Syria on the basis of 'regime's crimes. ${ }^{77}$ Saudi officials stated that support for military action was rooted in the desire to support and protect 'brothers in Syria', emphasising a humanitarian link with the population of Syria. ${ }^{78}$ The moral stance of Saudi Arabia is rooted in the concept of the greater transnational identity that links in to other Sunni Muslim populations. This is not to undermine the political realism that also underlies Saudi's alliance with the US, or its military actions in Yemen, however, it is in the language used that moralism as a legitimating force becomes evident and supports an idealistic inflection to the realism within so called 'Islamic' International Relations.

Iran's history and religious stance, places it in direct opposition to Saudi Arabia. Similarly steeped in religion, Iran's Shi'a underpinnings and revolutionary anti-colonialist character uniquely positions it within predominantly Sunni regional politics. Laden with revolutionary ideology, Iran's foremost foreign policy advocates the 'liberation of mankind' through Islamic universalism. ${ }^{79}$ Iran's moral and strategic stance has driven its historic and contemporary 
alliances with various factions and political elites across the region. Its historical ties with the Allawite ruling power within Syria roots its actions in a moral claim to represent and protect these groups. After the US led attack on Syria in April 2018 in response to the alleged use of chemical weapons by Assad, Rouhani stated that:

'Iran has always helped and will continue to support oppressed nations in the region and around the globe... Iran is opposed to the use of chemical weapons on the basis of religious, legal and ethical standards, while at the same time it ... strongly condemns (using this) as an excuse to commit aggression against a sovereign state $^{, 80}$

Emphasising distinctly moral stance rooted in religious principles as well as international constructs of international law and ethics, Iran represents a distinct moral stance in the Syrian conflict. This does not negate any geopolitical or geostrategic motivations that may also be present, however, the acknowledgement of religious moralism highlights a different thread of idealism which pervades the broader concept of 'Islamic' Just War theory.

The actions of these two regional powers towards the conflict in Syria reveal how strategic self-interest can incorporate religious outlook without the conspicuous moral claims to intervention as seen from Russia, or in elements of the just war arguments voiced by the UK and US. Iran and Saudi Arabia only represent two rather polarised forms of Islamic political moral frameworks, such as they are. Further still, no singular Islamic tradition can be identified and, therefore, moral common ground - religious-based or otherwise - is thus far unsubstantiated amongst these two regional powers. This is not to say that there is no moral claim from these nations as a basis for their interventions, but that morality is buried below overriding political and strategic concerns.

The next section looks further at this mixed relationship between morality and military intervention discourses concerning Syria and shifts to the individualised manipulation of moral 
discourses by jihadists. This is the last analytical level of the Syrian Babel which adds a fundamentally important component of the moral debate both rooted and displaced by the moral pillars discussed above. As Ali Brahimi noted, even 'the jihadi inhabits a moral universe, the boundaries of which are constantly contested' ${ }^{81}$ As discussion turns to the moral basis of the jihad in and around Syria, further complications and questions are presented as individuals stake a moral claim to the conflict. Distinct challenges to Walzer's Western just war assumptions emerge: specifically, the secular, state-centric, non-religious basis of his just war is contradicted in a morality where individual religious convictions and notions of the Divine dominate.

\section{Syria and the morality of the jihad}

'To us Afghanistan seemed very far away. To members of al Qaeda, America seemed very close. In a sense, they were more globalized than we were'. ${ }^{82}$

In the 15 years following the events in the United States on the 11th September 2001, the security and intelligence, as well as academic and policy, communities have each wrestled (largely separately) with the global and seemingly perpetual phenomena of 'the jihad' ${ }^{83}$ : a term that broadly encompasses the variety of 'connected' quasi-conflicts and acts of terrorism often labelled as Islamist, Jihadist, extremist or terrorist. The stark admission in the 9/11 Report above is a rare but important one that the various interested communities have yet to fully reconcile. This section explores the possibility that morality, or at least moral claims, contributed to them being 'more globalized than we were' ${ }^{84}$ in using social, old and new media to establish and maintain support for political violence within and beyond Syria, transcending the state-based international system and the state-oriented morality of Walzer's Western just war.

The 9/11 hijackers or the young Britons, for example, physically going to join ISIS are just as enabled by globalization to make the physical journey as the many more who participate at home. In different ways (emotionally, intellectually, spiritually) those 'at home' engage in 'the jihad' most often through social media, while being similarly incensed by perceived or actual 
actions against 'distant others' ${ }^{85}$ Those willing to act violently are limited in number, but their sense of love, hatred and anger is shared by many others who would never project it outwards in violence.

Thus far, various interested communities and organizations have failed to resolve where the non-violent 'contributors' to the discourse of the jihad sit in our frames of reference. It is probably pushing any definition of a 'jihadist' too far to include people sharing fairly reasonable memes on Israeli settlers or suchlike. Yet such 'contributions' do matter, the online discourse and community on social media related to Syria coalesces with material on other conflicts and issues from the more ardent and militant 'contributors'. Creating what is (perhaps surprisingly) a relatively pluralist and cosmopolitan environment. Fabre challenges the communitarianism of Walzer's moral arguments concerning war: 'In contrast to the still rather statist overtones of the just war tradition, the literature on the ethics of international relations has been characterized over the last two or three decades by a revival of the cosmopolitan tradition. ${ }^{86}$ Further, Hoskins et al have noted: 'The catharsis offered by the media or virtual jihad has proven sufficiently efficacious to supplant traditional notions of jihad for a new generation of jihadists, unwilling or unable to engage in actual violence themselves' ${ }^{87}$ This complex landscape of the morality of the jihad stands in stark contrast with the binary nature of categorisation that comes with the term, and process, of 'radicalization' and the limited narrative it offers to Western policy makers. If the thoughts and emotions of the sympathetic but non-violent 'jihadist' is securitized in the same way as physical actors in the jihad, there is a risk of alienating whole sectors of the population and further distancing the security forces from the moral aspects of Syria and the jihad, causing further misunderstanding of the threat faced. As a result of this complexity, the subtleties of morality and the jihad are often ignored or left to Islamic scholars to contest in isolation.

Morality discourses in the jihad have thus become unruly expressions and acts of freedom from mainstream, ordered, often state-based power structures. Syria cannot be easily separated from Kashmir, Chechnya, Palestine and other conflicts subject to overlapping and often 
contradictory moral discourse in the jihad. No authority is capable of exerting overall control and individuals dictate their personal moral agenda, subjecting the issues to their own bias. Syria is a moral as well as political and security issue, as demonstrated in the language and imagery in the tweet by MuslimGirl.net below (

Figure 1), which is one example of many. Material and behaviour such as this is rightly not labelled as 'jihadist' discourse, yet a relationship exists between the 'non-jihadist' moral discourse with its concern for the vulnerable, and more militant jihadist discourse using the same issues to advocate physical violence.

For some in the security communities, this would mean acknowledging the limitations of simple binary distinctions of 'good' and 'evil' and engaging with the much more difficult ambiguous and complex moral 'grey areas'. There are challenges in adopting this more nuanced approach and moving away from looking for the radicalized individual who makes a drastic leap from 'good schoolboy/girl' to ISIS jihadist, or from non-combatant to combatant: an approach that is thus far failing because it frames resulting understandings of belief and behaviour from the outset. Jenkins starkly makes the case for more nuanced efforts to better understand 'radicalization' as an individualised instance of human agency at work rather than a binary process:

We are likewise inclined to see terrorists as fiends, wild-eyed expressions of evil, diabolical but two-dimensional, somehow alien - in a word, inhuman. Government officials routinely denounce terrorists as mindless fanatics, savage barbarians, or more recently, 'evildoers' - words that dismiss any intellectual content and impede efforts to understand the enemy. ${ }^{88}$ 
The failing orthodox approach Jenkins describes here is one that attempts to sit outside of the subject's context to give a supposedly fair and untainted judgement on what is seen. If jihadists are simplistically labelled as evildoers there is a risk not only of methodological inaccuracy, but also a crucial lack of appreciation of cultural context in which the jihad and discussions of its morality are situated. In addition, it overlooks the extent to which empathy and social concern act as personal motivators in a realm so predominantly associated with religiouslyinformed ideology. Devji provides a contextual understanding of the jihad that goes beyond simple perceptions of evil-doing or religiously-motivated violence:

For Al-Qaeda's violence, while certainly the most visible aspect of the jihad, is linked to a whole world of beliefs and practices that remains invisible in much scholarly writing on the subject. This invisible world of ethical, sexual, aesthetic and other forms of behaviour is far more extensive than the jihad's realm of violence. ${ }^{89}$

The moral dimension of the jihad as applied to Syria is similarly 'invisible' and consistently overlooked, a problem Devji recognised in speaking about the jihad a decade previously. This is partly because morality is found in the everyday, more mundane or prosaic elements of 'jihadist activity' and these do not grab public attention. ${ }^{90}$ Public, media and political focus is, perhaps understandably, on the immediacy of violence and the response of the security services. As a result the narrative of 'radicalization' has become a stubborn, if limited and limiting, barrier to deeper inquiry into the more extensive 'invisible world' of morality and the jihad. As Berger puts it: 'There's a strong argument to be made that our national conversation about radicalization has expanded far beyond its mandate and its usefulness...Radicalization is [only] one component in understanding terrorism'. ${ }^{91}$ Radicalization discourse encourages a good/evil binary that limits appreciation of the discourses on violent acts, conflicts, polices, regimes and interventions that draw people together through emotional ties and content. Brahimi has noted this in how 
the recurring focus on 'nihilism' and 'evil' works to obscure the refined Islamic reasoning underpinning bin Laden's [and others including Baghdadi's] case for war, which, in turn, undervalues the potential mass appeal of his self-defined 'liberation' movement among disenfranchised Muslims. ${ }^{92}$

Given overt cries for Syria's liberation, from all 'sides', much of the coverage on Syria's various moral discourses falls into the binary trap. Githens-Mazer and Lambert argue that this is 'not only naive but may actually be counterproductive'. ${ }^{93}$ Radicalization is limited as a conceptual framework because it cannot recognize the relationship between a banal meme about Palestine shared by a middle class British citizen, and a militant jihadist in Syria whose actions are a violent representation of a broader, more deeply entrenched empathetic groundswell using the same meme. Returning to the Walzerian assumption of a commonly understood morality vocabulary, we see here in the discourse of the jihad consistent uses of familiar terms to promote unfamiliar moral concepts.

Ahmed refers to the 'grey zone' between these two positions - good/evil or radicalised/non-radicalised. ${ }^{94}$ Given that binary is also desired by ISIS to further its own ends, it is perhaps time to reconsider understandings and approaches of moral claims in jihadist discourse. Atran seeks to protect the 'grey zone' quoting ISIS's online magazine, Dabiq, which explicitly argues: 'the time had come for another event to ... bring division to the world and destroy the grey zone'. ${ }^{95}$ That 'grey zone' includes the notion of the jihadist pursuing humanitarian ideals as Devji observes:

Given that militants today routinely invoke the plight of suffering Muslims in exactly the same way that humanitarians do of victims in general... Indeed, humanitarian actions even serve as the model for militant interventions in the contemporary rhetoric of jihad. ${ }^{96}$ 
Such a view is reinforced by Pinker, who states, 'Far from being ignorant, impoverished, nihilistic, or mentally ill, suicide terrorists tend to be educated, middle class, morally engaged, and free of obvious psychopathology'.97 Exploring individual jihadist motivations, he found collective, socialized answers: 'Commitment to the group is intensified by religion, not just the literal promise of paradise but the feeling of spiritual awe that comes from submerging oneself in a crusade, a calling, a vision quest, or the jihad. ${ }^{98}$ Combining these ideas it becomes apparent that the telos, the ultimate aim of jihadists, is a complex, multifarious end, comprising social acceptance, community status and personal meaning, none of which depend on achieving statehood in a Westphalian sense. Atran highlights the moral commitment involved, with the associated security implications for trying to defeat jihadists and the religious-political justification that underpins their actions: 'As long as jihadis show such moral commitment, as martyrdom missions attest to, then even overwhelming material efforts to destroy the jihadi movement may not be enough. But what gets group commitment going in the first place?'99 Atran's line of inquiry leads to the possibility that jihad is not initially pursued by bad people doing bad things, even if that eventually occurs, but by people who consider themselves good and who want to do 'good' things in pursuit of some sense of global 'social purpose'. ${ }^{100}$ Syria is the latest issue absorbed into this amorphous groundswell of individuals searching for such social purpose.

The cosmopolitan commitment to others seen in 'jihadist' discourse is evidently displayed on public social media platforms. There is significant, though not total, common ground in the rhetoric and justification of the use of force in this complex discourse with the words of President Obama and David Cameron about individual human suffering needing to be recognised and used as common ground for dialogue and endeavours towards understanding competing moral claim and counter-claim in Syria.

\section{Conclusion}


This examination of some of the moral motivations for action (and inaction) in the on-going Syria conflict has highlighted a number of crucial moral and political differences - and some moral commonalities - that can be overlooked if moral assessment is conducted through a single moral lens, such as Western just war. Perhaps the most surprising - as well as the most challenging to Western security interests - is the altruistic, morally motivated aspect of the jihad, and the many observers and commentators cheering their cause through social media from far away. Nuance can be easily missed in the bloodshed and violence that causes immediate humanitarian distress, and when moral outrage prevents us from fully comprehending the cause.

A pattern of adoption and adaption of similar (if opposing) state perspectives on the orthodox just war case for the use of military force in Syria can be identified. In parallel, the language of revisionist just war arguments are mirrored in many ways in the jihad, with both prioritising a concern for the individual. This hybridity, across sides of the conflict and levels of morality (individual, state, divine), indicates a common human tendency toward righteous violence on broad 'humanitarian' grounds. As the foregoing arguments indicate, these grounds are often cultivated in specific social, cultural and political contexts and defy universal application. National, ethnic, religious and many other cleavages prevent dialogue at state level even where there are moral commonalties. The most transparent examples of where a cosmopolitan form of altruism around Syria is seen, are on digital platforms where individuals and groups coalesce around specific events, issues and foes. Often this coalescence is fleeting - and can oppose both Western and conventional Islamic moralities - before further disagreement and fracture. Far from being merely ephemeral, the 'Clicktivism' on the moral discourses on Syria should not be disregarded by a crude application of just war or other moral lenses: Western or otherwise. State polities that listen to, and comprehend, the breadth of this moral groundswell will prove more responsive to the violence and other social action that emerges from it. A moral Babel is not reborn in Syria: there is sufficiently common moral language being used by all sides for a degree of common meaning to emerge - as Walzer proposed. However, moral incommensurabilities 
also need to be recognised if protagonists are to listen and really hear what is being said and truly understand the moral motivations of their opponents. 


\section{Figures}

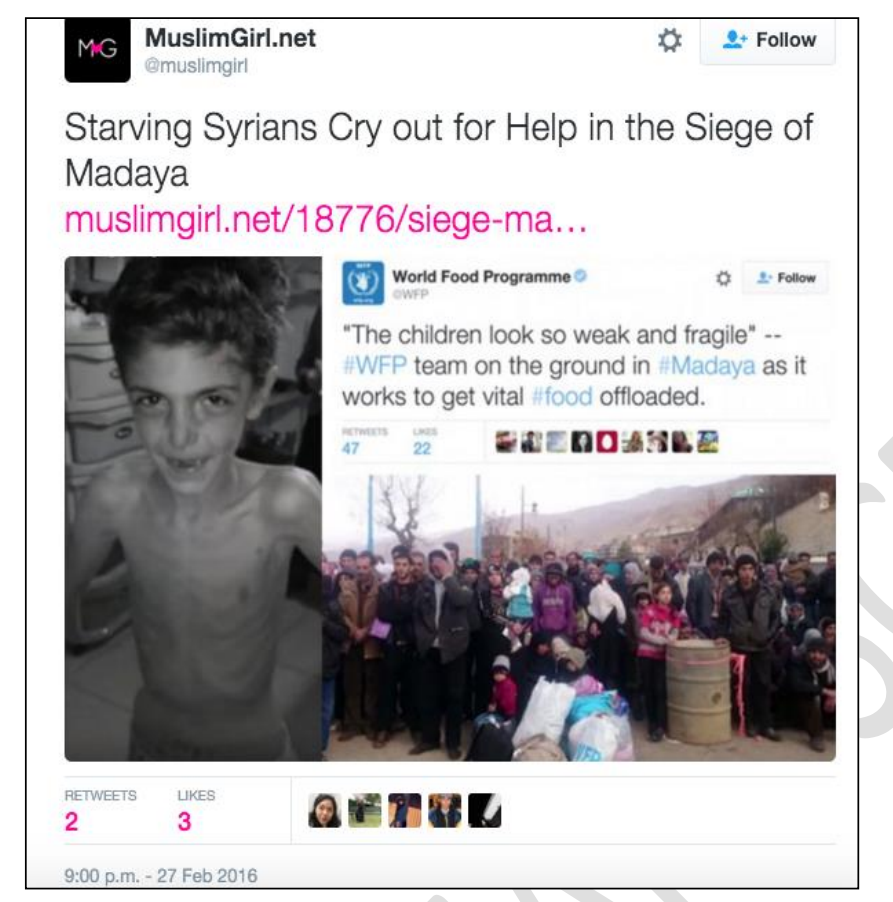

Figure 1 - Syria is a moral as well as political and security issue (tweet by MuslimGirl.net) ${ }^{101}$ 


\section{Notes}

${ }^{1}$ This paper was prompted by the DSTL-funded project report, see Peter Lee et al., 'Perspectives Around Syria:
Moralities in Conflict', TIN 3.193 - Understanding the Moral Component of Conflict (Defence Science and
Technology Laboratory, 31 March 2016), https://researchportal.port.ac.uk/portal/en/projects/perspectives-
around-syria-moralities-in-conflict(c8f550ef-3f7c-456f-89e0-eacOcb090eae).html.
${ }^{2}$ Tom Switzer, 'Syria Is a Morally Ambiguous Conflict', The Sydney Morning Herald, 16 October 2016,
http://www.smh.com.au/comment/syria-is-a-morally-ambiguous-conflict-20161016-gs3c3t.html.
${ }^{3}$ Paulo Sérgio Pinheiro, 'OHCHR I Statement by the Chair of the Independent International Commission of
Inquiry on the Arab (2014), https://www.ohchr.org/EN/HRBodies/HRC/Pages/NewsDetail.aspx?NewsID=14731\&LangID=E; Paulo Sérgio Pinheiro, 'OHCHR | Statement by Mr. Paulo Sérgio Pinheiro Chair of the Independent International Commission of Inquiry on the Syrian Arab Republic' (2014), https://www.ohchr.org/EN/NewsEvents/Pages/DisplayNews.aspx?NewsID=14397\&Lang\%20ID=E.

${ }^{4}$ United Nations, 'Report on the Alleged Use of Chemical Weapons in the Ghouta Area of Damascus on 21 August 2013', United Nations Mission to Investigate Allegations of the Use of Chemical Weapons in the Syrian Arab Republic, 13 September 2013, http://www.un.org/zh/focus/northafrica/cwinvestigation.pdf.

${ }^{5}$ (first) Center for Documentation of Violations in Syria, 'The Classification of Violations in the Center', 2011, http://www.vdc-sy.info/index.php/en/about.

${ }^{6}$ Nadje Al-Ali, 'Sexual Violence in Iraq: Challenges for Transnational Feminist Politics', European Journal of Women's Studies 25, no. 1 (1 February 2018): 10-27, doi:10.1177/1350506816633723.

${ }^{7}$ UN Human Rights Council, 'Report of the Independent International Commission of Inquiry on the Syrian Arab Republic' (United Nations, 16 August 2012), http://www.ohchr.org/Documents/HRBodies/HRCouncil/RegularSession/Session21/A-HRC-21-50_en.pdf.

${ }^{8}$ Gulnaz Sharafutdinova, 'The Pussy Riot Affair and Putin's Démarche from Sovereign Democracy to Sovereign Morality', Nationalities Papers 42, no. 4 (4 July 2014): 616, doi:10.1080/00905992.2014.917075.

9 David Cameron, 'Statement to Parliament on Counterterrorism', 9 July 2015, col. 23, https://publications.parliament.uk/pa/cm201516/cmhansrd/cm150907/debtext/150907-0001.htm.

10 Tom Smith, 'Why Trump's Syrian Strike Was a Good Thing', The Conversation, 10 April 2017, http://theconversation.com/why-trumps-syrian-strike-was-a-good-thing-76024.

${ }^{11}$ Michael Walzer, Just and Unjust Wars: A Moral Argument With Historical Illustrations, 3rd edition (New York: Basic Books, 2000), xix.

12 Ibid., xxi.

${ }^{13}$ Ibid.

${ }^{14}$ The Jihad refers to a term that broadly encompasses the variety of 'connected' quasi-conflicts and acts of terrorism and issues often labelled as Islamist, Jihadist, extremist or terrorist, from Syria to the London terrorist attacks. This understanding of the term 'the jihad' is based on Faisal Devji, Landscapes of the Jihad: Militancy, Morality and Modernity (C Hurst \& Co Publishers Ltd, 2005), xv.

${ }^{15}$ Amnesty International, 'Death Everywhere' War Crimes and Human Rights Abuses in Aleppo, Syria' (United Kingdom: Amnesty International, 2015), 6, https://www.amnestyusa.org/reports/death-everywhere-warcrimes-and-human-rights-abuses-in-aleppo/.

16 UN Security Council, 'Report of the Secretary General', 16 February 2017, http://www.securitycouncilreport.org/atf/cf/\%7B65BFCF9B-6D27-4E9C-8CD3-

CF6E4FF96FF9\%7D/s_2017_144.pdf.

${ }^{17}$ United Nations, 'Report on the Alleged Use of Chemical Weapons in the Ghouta Area of Damascus on 21 August 2013'.

${ }_{18}$ UNHCR, 'Syria Regional Refugee Response', 19 October 2017, http://data.unhcr.org/syrianrefugees/regional.php.

${ }^{19}$ UNHCR, 'Syria Emergency', 30 May 2017, http://www.unhcr.org/uk/syria-emergency.html.

${ }^{20}$ John Bew, 'The Syrian Tragedy and the Crumbling of World Order', New Statesman, September 2015.

${ }^{21}$ Roula Khalaf and A. Fieldin-Smith, 'Qatar Bankrolls Syrian Revolt with Cash and Arms', Financial Times, 16 May 2013, http://www.ssig.gov.my/wpcontent/uploads/2013/07/Qatar_bankrolls_Syrian_revolt_with_cash_.pdf; Gareth Porter, 'Obama's Failure on Saudi-Qatari Aid to Al-Qaeda Affiliate', Middle East Eye, 23 May 2015, http://www.middleeasteye.net/columns/obama-s-fail-saudi-qatari-aid-al-qaeda-affiliate-1176814251. 
${ }^{22}$ Edward Dark, 'Pro-Regime Sunni Fighters in Aleppo Defy Sectarian Narrative', Al-Monitor, 14 March 2014, http://www.al-monitor.com/pulse/originals/2014/03/syria-aleppo-sunni-quds-baath-brigades.html;

Aymenn Jawad al-Tamimi, 'A Case Study of "The Syrian Resistance," a Pro-Assad Militia Force', Syria Comment, 22 September 2013, http://www.joshualandis.com/blog/aymenn-al-tamimi-speaks-to-ali-kayaliand-profiles-the-syrian-resistance-a-pro-assad-militia-force/.

${ }^{23}$ Talal Nizameddin, 'Squaring the Middle East Triangle in Lebanon: Russia and the Iran-Syria-Hezbollah Nexus', The Slavonic and East European Review 86, no. 3 (2008): 479.

24 Geneive Abdo, 'How Iran Keeps Assad in Power in Syria', Foreign Affairs, 25 August 2011, https://www.foreignaffairs.com/articles/iran/2011-08-25/how-iran-keeps-assad-power-syria; Jonathan Gelbart, 'Iran-Syria Axis: A Critical Investigation', Stanford Journal of International Relations 7, no. 1 (2010): 88-102; Nizameddin, 'Squaring the Middle East Triangle in Lebanon'.

25 Jeff McMahan, Killing in War, Reprint edition (New York: Oxford University Press, U.S.A., 2011).

${ }^{26}$ Walzer, Just and Unjust Wars, 61-62.

27 Barack Obama, 'A Just and Lasting Peace' (Nobel Lecture, Olso, 10 December 2009), https://www.nobelprize.org/nobel_prizes/peace/laureates/2009/obama-lecture_en.html.

${ }^{28}$ Barack Obama, 'Statement by the President on Syria' (Office of the Press Secretary, The White House, 31 August 2013), https://obamawhitehouse.archives.gov/the-press-office/2013/08/31/statement-presidentsyria.

${ }^{29}$ Barack Obama, 'Remarks by President Obama to the United Nations General Assembly' (UN General Assembly, United Nations Headquaters, New York, 28 September 2015), https://obamawhitehouse.archives.gov/the-press-office/2015/09/28/remarks-president-obama-united-

nations-general-assembly.

${ }^{30}$ Ibid.

31 David Cameron, Syria: transcript of PM's interview, 27 August 2013, https://www.gov.uk/government/speeches/syria-transcript-of-pms-interview.

32 HM Government, 'Chemical Weapon Use By Syrian Regime - UK Government Legal Position', 29 August 2013, https://www.gov.uk/government/uploads/system/uploads/attachment_data/file/235098/Chemicalweapon-use-by-Syrian-regime-UK-government-legal-position.pdf.

33 lbid.

${ }^{34}$ Hansard (Commons), 'House of Commons Hansard Debates', Vol. 566 Col. 1479, 1496, (29 August 2013), cols 1479, 1496, https://publications.parliament.uk/pa/cm201314/cmhansrd/cm130829/debtext/1308290002.htm\#13082913000045.

35 James Strong, 'Interpreting the Syria Vote: Parliament and British Foreign Policy', International Affairs 91, no. 5 (1 September 2015): 1127, doi:10.1111/1468-2346.12401.

${ }^{36}$ Cameron, 'Statement to Parliament on Counterterrorism', col. 23.

${ }^{37}$ Ibid.

38 Jeremy Wright, 'Attorney Genral - Oral Evidence Taken before the Justice Select Committee' (House of $\begin{array}{llll}\text { Commons, } & 15 & \text { September } 2015), & 409 \text {, }\end{array}$ http://data.parliament.uk/writtenevidence/committeeevidence.svc/evidencedocument/justicecommittee/the-work-of-the-attorney-general/oral/21698.pdf.

${ }^{39}$ Jeff McMahan, 'The Sources and Status of Just War Principles', Journal of Military Ethics 6, no. 2 (1 June 2007): 91-106, doi:10.1080/15027570701381963.

40 Walzer, Just and Unjust Wars, 61-62.

${ }^{41}$ Ibid., 54.

42 Lynn E. Davis, Michael McNerney, and Michael D. Greenberg, 'Clarifying the Rules for Targeted Killing', Product Page (RAND Corporation, 2016), https://www.rand.org/pubs/research_reports/RR1610.html.

${ }^{43}$ Alan Greene, Verity Adams, and Jane Rooney, 'The Legal Regulation of UAV Strikes Abroad: The Legality of UAV Strikes under International Humanitarian, International Human Rights and UK Constitutional Law', § Joint Committe Human Rights (2015), http://data.parliament.uk/WrittenEvidence/CommitteeEvidence.svc/EvidenceDocument/Human\%20Rights \%20Joint\%20Committee/The\%20UK\%20Governments\%20policy\%20on\%20the\%20use\%20of\%20drones\%20 for\%20targeted\%20killing/written/24533.html.

44 Ian Clark, 'Taking "Justness" Seriously in Just War: Who Are the "Miserable Comforters" Now?', International Affairs 93, no. 2 (1 March 2017): 331, doi:10.1093/ia/iix003.

${ }^{45}$ Vladimir Putin, '70th Session of U.N. General Assembly Address', Washington Post, 28 September 2015, sec. WorldViews, https://www.washingtonpost.com/news/worldviews/wp/2015/09/28/read-putins-u-ngeneral-assembly-speech/.

${ }^{46}$ Roy Allison, 'Russia and Syria: Explaining Alignment with a Regime in Crisis', International Affairs 89, no. 4 (1 July 2013): 795-823, doi:10.1111/1468-2346.12046. 
47 Putin, '70th Session of U.N. General Assembly Address'.

48 Ibid.

${ }^{49}$ Derek Averre and Lance Davies, 'Russia, Humanitarian Intervention and the Responsibility to Protect: The Case of Syria', International Affairs 91, no. 4 (2015): 813-834.

50 Shavkat Kasymov, 'Statism in Russia: The Implications for US-Russian Relations', The Journal of Slavic Military Studies 24, no. 3 (2011): 534.

${ }^{51}$ Gerald M. Easter, 'The Russian State in the Time of Putin', Post-Soviet Affairs 24, no. 3 (2008): 200.

${ }^{52}$ Christina Cottiero et al., 'War of Words: The Impact of Russian State Television on the Russian Internet', Nationalities Papers 43, no. 4 (2015): 536.

53 Iver B. Neumann, 'Russia's Europe, 1991-2016: Inferiority to Superiority', International Affairs 92, no. 6 (2016): 1381-1399.

54 Sharafutdinova, 'The Pussy Riot Affair and Putin's Démarche from Sovereign Democracy to Sovereign Morality', 615.

55 Ibid., 616.

${ }^{56}$ Vladimir Putin, 'Vladimir Putin Addresses Russia's Intentions in Syria', CBS News, 24 September 2015, https://www.cbsnews.com/news/vladimir-putin-addresses-russias-intentions-in-syria/.

57 Vladimir Putin, 'Interview to Vladimir Solovyov', Office of the Russian Presidency, 12 October 2015, http://en.kremlin.ru/events/president/news/50482.

${ }^{58}$ Nicolai N. Petro, 'Russia's Orthodox Soft Power', Carnegie Council for Ethics in International Affairs, 23 March 2015, https://www.carnegiecouncil.org/publications/articles_papers_reports/727.

59 Office of the Russian Presidency, 'Meeting of the Valdai International Discussion Club', 22 October 2015, http://en.special.kremlin.ru/events/president/news/50548.

60 IISS, 'Russia's Syrian Stance: Principled Self-Interest', Journal of the International Institute for Strategic Studies 18 (2012).

${ }^{61}$ Roland Oliphant, 'Vladimir Putin Denies Bombing Syrian Civilians', The Telegraph, 12 January 2016, sec. World, http://www.telegraph.co.uk/news/worldnews/vladimir-putin/12094989/Vladimir-Putin-deniesbombing-Syrian-civilians.html.

${ }^{62}$ Owen Matthews, 'Putin's Winning in Syria - but Making a Powerful New Enemy', The Spectator, 20 February 2016, https://www.spectator.co.uk/2016/02/putins-winning-in-syria-but-making-a-powerful-new-enemy/.

63 John Kelsay, 'Islamic Tradition and the Justice of War', in The Ethics of War in Asian Civilisations, ed. Torkel Brekke (Routledge, 2006), 86.

${ }^{64}$ Sohail Hashmi, 'Interpreting the Islamic Ethics of War and Peace', in The Ethics of War and Peace: Religious and Secular Perspectives, ed. Nardin, Terry, 1996, 148.

65 Ibid., 150-51.

${ }^{66}$ John Kelsay, Arguing the Just War in Islam (Harvard University Press, 2009).

${ }^{67}$ Karen Armstrong, Holy War: The Crusades and Their Impact on Today's World (Anchor, 2001), 25.

${ }^{68}$ Abdulaziz A. Sachedina, 'The Development of Jihad in Islamic Revelation and History', in Cross, Crescent, and Sword, ed. James Turner Johnson and John Kelsay, 1990, 35.

${ }^{69} \mathrm{Al}$-Siyar was a 'self-imposed system of law, the sanctions of which were moral or religious and binding on its adherents even though the rules ran counter to their interests' Shaybânî Siyar and Majid Khadduri, The Islamic Law of Nations (Trans.) (Baltimore, USA: The Johns Hopkins Press., 1966), 6., 'it made no discrimination among foreigners and dealt equitably with the non-Muslim states of the entire world','Abd ar-Rahman I. Doi, Shariah: Islamic Law (London: Ta-Ha Publishers Ltd, 1984), 421.. Al-siyar emulated the nature of Islam as being 'inherently personal' Ibid., 7. .

70 Kelsay, 'Islamic Tradition and the Justice of War', 103.

${ }^{71}$ Ibid.

72 Thomas Aquinas, Summa Theologica (Trans.), trans. trans. Fathers of the English and Fathers of the English Dominican Province (New York: Benziger Bros, 1948), 1813.

73 Ministry of Foreign Affairs, 'The Foreign Policy of The Kingdom of Saudi Arabia', 8 May 2016, http://www.mofa.gov.sa/sites/mofaen/KingdomForeignPolicy/Pages/ForeignPolicy24605.aspx.

${ }^{74}$ Anoushiravan Ehteshami, 'The Foreign Policy of Iran', in The Foreign Policies of Middle East States (Boulder, Colo: Lynne Rienner, 2002), 85.

75 Fred Halliday, Revolution and Foreign Policy: The Case of South Yemen, 1967-1987 (Cambridge University Press, 1990), 27.

${ }^{76}$ Ministry of Foreign Affairs, 'The Foreign Policy of The Kingdom of Saudi Arabia'.

77 Joyce Karam, 'Saudi Arabia Fully Supports US-Led Strikes on Syria', The National, 14 April 2018, https://www.thenational.ae/world/mena/saudi-arabia-fully-supports-us-led-strikes-on-syria-1.721403. 


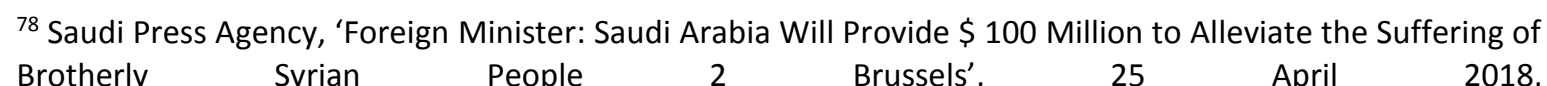
https://www.spa.gov.sa/viewstory.php?lang=en\&newsid=1756532

${ }^{79}$ Rouhollah K. Ramazani, 'Khumayni's Islam in Iran's Foreign Policy', in Islam in Foreign Policy, ed. Adeed Dawisha, vol. 1983 (Cambridge: Cambridge University Press, 1983), 9-32.

${ }^{80}$ Our Foreign Staff, "'An Unequivocal Message”: How the World Reacted to the Syrian Airstrikes', The Telegraph, 15 April 2018, https://www.telegraph.co.uk/news/2018/04/14/unequivocal-message-worldreacted-syrian-airstrikes/.

${ }^{81}$ Alia Brahimi, Jihad and Just War in the War on Terror (New York, NY: OUP Oxford, 2010 ), 1.

82 The National Commission on Terrorist Attacks Upon the United States, The 9/11 Commission Report: The Full Final Report of the National Commission on Terrorist Attacks Upon the United States (W. W. Norton \& Co., 2004), 339.

${ }^{83}$ Devji, Landscapes of the Jihad: Militancy, Morality and Modernity, xv.

${ }^{84}$ The National Commission on Terrorist Attacks Upon the United States, The 9/11 Commission Report, 339.

${ }^{85}$ Andrew Linklater, 'Distant Suffering and Cosmopolitan Obligations', International Politics 44, no. 1 (20 December 2006): 19-36, doi:10.1057/palgrave.ip.8800156.

${ }^{86}$ Cecile Fabre, 'Cosmopolitanism, Just War Theory and Legitimate Authority', International Affairs 84, no. 5 (1 September 2008): 963-76, doi:10.1111/j.1468-2346.2008.00749.x.

${ }^{87}$ Andrew Hoskins, Akil Awan, and Ben O'Loughlin, Radicalisation and Media: Connectivity and Terrorism in the New Media Ecology (Taylor \& Francis, 2011), 64.

${ }^{88}$ Brian Michael Jenkins, Unconquerable Nation Knowing Our Enemy, Strengthening Ourselves (Santa Monica, CA: RAND Corp., 2006), 53, http://public.eblib.com/EBLPublic/PublicView.do?ptiID=784073.

${ }^{89}$ Devji, Landscapes of the Jihad: Militancy, Morality and Modernity, xv.

${ }^{90}$ Aditya Chakrabortty:, 'Are Al-Qaida and the Taliban Driven by the Desire to Help Others?', The Guardian, 3 May 2011, http://www.theguardian.com/commentisfree/2011/may/03/are-islamist-terrorists-basicallyaltruistic.

91 J. M Berger, 'Myths of Radicalization', Inte/wire, 8 May 2013, http://news.intelwire.com/2013/05/mythsof-radicalization.html?utm_source=feedly\&m=1it.

92 Brahimi, Jihad and Just War in the War on Terror, 4.

93 Jonathan Githens-Mazer and Robert Lambert, 'Why Conventional Wisdom on Radicalization Fails: The Persistence of a Failed Discourse', International Affairs 86, no. 4 (2010): 900, doi:10.1111/j.14682346.2010.00918.x.

94 Nafeez Mosaddeq Ahmed, 'ISIS Wants to Destroy the "Grey Zone". Here's How We Defend It', OpenDemocracy, 16 November 2015, https://www.opendemocracy.net/nafeez-ahmed/isis-wants-destroygreyzone-how-we-defend.

${ }^{95}$ Scott Atran, 'Mindless Terrorists? The Truth about Isis Is Much Worse', The Guardian, 15 November 2015, sec. Opinion, http://www.theguardian.com/commentisfree/2015/nov/15/terrorists-isis.

96 Faisal Devji, 'The Terrorist as Humanitarian', Social Analysis 53, no. 1 (30 May 2009): 175, doi:10.3167/sa.2009.530111.

${ }^{97}$ Steven Pinker, The Better Angels of Our Nature: Why Violence Has Declined, Reprint edition (Penguin Books, 2012), 282.

98 Ibid., 284.

${ }^{99}$ Scott Atran, Talking to the Enemy: Faith, Brotherhood, and the (Un)Making of Terrorists (New York: Ecco Press, 2010), 298.

100 P. Nelson et al., 'Restructuring World Politics: Transnational Social Movements, Networks, and Norms', 2002, http://202.120.227.5:8080/harvard/links500/d165.doc.

${ }^{101}$ MuslimGirl.net [muslimgirl], 'Starving Syrians Cry out for Help in the Siege of Madaya', 27 February 2016, https://t.co/MQ8B9ZNsv7 https://t.co/dXsrhFmmoh [Tweet], retrieved from https://twitter.com/muslimgirl/status/703686172757893120, accessed 2 March 2016. 


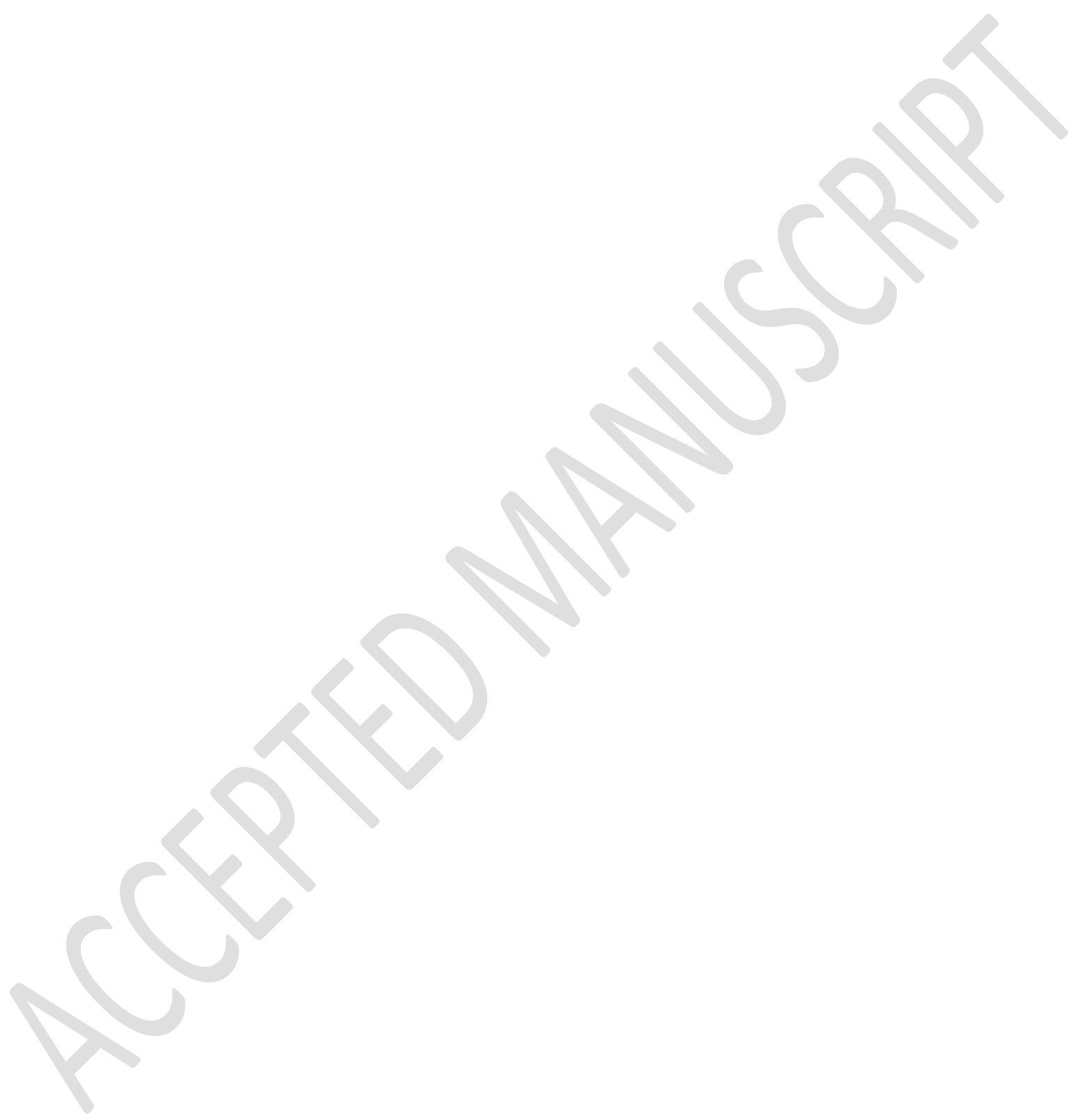

